\title{
SUTRIKUSIO INTELEKTO ASMENŲ PSICHOMOTORINĖS REAKCIJOS YPATUMAI
}

\author{
Diana Rẻklaitienė, Dovilè Selickaitė, Jūratė Požerienė \\ Lietuvos kūno kultūros akademija, Kaunas, Lietuva
}

\begin{abstract}
Diana Rèklaitienė. Socialinių mokslų daktarè. Lietuvos kūno kultūros akademijos Taikomosios fizinès veiklos katedros docentė. Moksliniu tyrimų kryptis - sutrikusio intelekto asmenu psichomotorinè raida, neigaliujų reabilitacija per šokị ir gimnastiką.
\end{abstract}

\begin{abstract}
SANTRAUKA
Žmogaus reakcijos i Łvairiausius signalus tyrimo metodai leidžia atrasti vis naujas savybes ir formuoti nauja požiūri $\dot{\imath}$ propriorecepcijos, pusiausvyros aparato, regos, nervu ir raumenu sistemu visumine veikla (Weeks et al., 2000; Gut et al., 2007; Zuozienè, 2007). Psichomotorine reakcija svarbi sutrikusio intelekto asmenims kasdieniame gyvenime, nes einant gatve, dirbant, sportuojant, tenkinant kasdienius poreikius ar užsiimant rekreacine veikla kartais bütina daryti greitus sprendimus dèl atitinkamu veiksmu numatytomis ar nenumatytomis situacijomis (Weeks et al., 2000; Pratt, Greydanus, 2007). Kadangi vienas iš sutrikusio intelekto asmenu vystymosi ypatumu yra sutrikusi psichomotorine raida, šia tema reikètu atlikti tyrimus, kurie padètu stebèti CNS funkcinès büklès pokyčius. Reakcijos laikas labai svarbus ne tik motorinei raidai, bet ir geresniam, greitesniam prisitaikymui prie besikeičiančiu gyvenimo sqlygu.
\end{abstract}

Tyrimo tikslas - ištirti ir ̨̇vertinti sutrikusio intelekto asmenu psichomotorinę reakcija. Siekdami užsibrèžto tikslo stengèmés atsakyti i šiuos klausimus: 1) kaip skiriasi iprastos ir sutrikusios raidos asmenu psichomotorine reakcija; 2) ar skiriasi sutrikusio intelekto asmenu paprasta ir sudetinga reakcija ̨ šviesq ir garsa; 3) ar priklauso sutrikusio intelekto asmenu psichomotorinè reakcija nuo sutrikimo laipsnio ir lyties.

Buvo tirtos trys 18-21 metu amžiaus tiriamuju grupès (iprastos raidos $(n=20)$, nežymiai protiškai atsilikusiu $(n=17)$ ir vidutiniškai protiškai atsilikusiu asmenu $(n=19))$. Psichomotorinei reakcijai išmatuoti buvo taikomas reakciometrijos metodas naudojant reakciometra $R A$-1, skirtq žmogaus reakcijos í raudonos ir žalios šviesos ar garsini signala trukmei matuoti, žmogaus centrinès nervu sistemos (CNS) psichomotorinès reakcijos greičio ypatumams nustatyti.

Lprastinès raidos tiriamieji pasiekè kur kas geresniu rezultatu atlikdami visas reakcijos laiko užduotis, lyginant su protiškai atsilikusiu tiriamuju grupèmis $(p<0,05)$. Visos tiriamuju grupés greičiau reagavo $\dot{\ell}$ garso nei $\dot{\text { šviesos }}$ dirgikli ir buvo geresni ju paprastos reakcijos laiko rezultatai nei sudètingos. Nežymiai protiškai atsilikusiu vaikinu reakcijos laikas buvo geresnis atliekant paprastos reakcijos laiko $i$ šviesq užduotis, o to paties protinio atsilikimo merginos greičiau atliko paprastos reakcijos laiko i garsq užduotis. Vidutiniškai protiškai atsilikusiu merginu reakcija i šviesq ir garsq yra geresne nei to paties protinio atsilikimo vaikinu.

Lprastos raidos tiriamieji darè daugiau klaidu nei sutrikusio intelekto asmenys, mažiausiai klaidu darè vidutiniškai protiškai atsilikę tiriamieji.

Raktažodžiai: sutrikęs intelektas, psichomotorine reakcija, reakcijos greitis.

\section{IVADAS}

I ntelekto sutrikimas apibūdinamas kaip protinių gebėjimų nukrypimas, sukeliantis elgesio, emociju ir socialinio prisitaikymo sutrikimu (Pratt, Greydanus, 2007). Nors, daugelio autoriu duomenimis, protiškai atsilikę vaikai ir paaugliai auga ir bręsta pagal bendruosius raidos dèsningumus, dauguma iš jų atsilieka fizinėmis ypatybėmis ir motorine raida (Grinienè, Puidaite, 2003). Sutrikusio intelekto asmenų motorinè raida gali būti sulètèjusi dèl vèliau pasireiškiančios bendrosios raidos: nedarnios kūno dalių, organų raidos, sutrikusios koordinacijos (Kioumourtzoglou et al., 1994; Song, An, 2004; Carmeli et al., 2008).

Moksliniai tyrimai parodè, kad protiškai atsilikusių vaiku jègos, ištvermès, judrumo, pusiausvyros, bėgimo greičio, lankstumo ir reakcijos laiko matavimo rezultatai yra prastesni negu ju igaliu bendraamžiu (Kioumourtzoglou et al., 1994; Gri- 
nienè, Puidaitè, 2003; Song, An, 2004; Carmeli et al., 2008). Palyginti su igaliaisiais, sutrikusio intelekto asmenys geba mažiau spontaniškai numatyti pasikeitusias sąlygas ir atlikti tam tikrą judesiu užduoti (Wuang, Su, 2009; Jang et al., 2009).

Žmogaus reakcijos i i ivairiausius signalus tyrimo metodai leidžia atrasti vis naujas savybes ir formuoti naują požiūri i propriorecepcijos, pusiausvyros aparato, regos, nervų ir raumenų sistemų visuminę veiklą (Weeks et al., 2000; Zuozienè, 2007; Wuang et al., 2009). Tyrimų metu gauti psichomotorinès reakcijos laiko duomenys teikia informacijos apie greiti, kuriuo impulsai sklinda nervų sistemoje, informacijos apdorojimą galvos smegenyse bei sprendimu prièmimo trukmę. Todèl iš reakcijos laiko galima spręsti apie centrinès nervų sistemos funkcinès būklès pokyčius (Weeks et al., 2000; Heath et al., 2007; Gut et al., 2007).

Psichomotorinè reakcija svarbi sutrikusio intelekto asmenims kasdieniame gyvenime, nes einant gatve, dirbant, sportuojant, tenkinant kasdienius poreikius ar užsiimant rekreacine veikla kartais būtina daryti greitus sprendimus dèl atitinkamų veiksmu numatytomis ar nenumatytomis situacijomis (Weeks et al., 2000; Pratt, Greydanus, 2007). Kadangi vienas iš sutrikusio intelekto asmenu vystymosi ypatumu yra sutrikusi psichomotorinè raida, šia tema reikètu atlikti tyrimus, kurie padètu stebėti CNS funkcinès būklès pokyčius. Reakcijos laikas yra labai svarbus ne tik motorinei raidai, bet ir geresniam, greitesniam prisitaikymui prie besikeičiančiu gyvenimo sąlygų. Tai yra vienas iš objektų, kuris domina šių laikų mokslininkus (Weeks et al., 2000; Un, Erbahceci, 2001; Song, An, 2004; Heath et al., 2007; Carmeli et al., 2008; Jang et al., 2009, Wuang et al., 2009). Pažinimas, psichomotorika ir tinkamas elgesys yra kintantys reiškiniai, kuriuos kryptingai ir aktyviai skatinant galima pasiekti kur kas geresnių rezultatu negu tikimasi (Song, An, 2004). Šiuo metu itin daug užsienio mokslininkų domisi neigaliu asmenų psichomotorinès raidos problemomis, tarp jų nemažai atliekama sutrikusio intelekto asmenu tyrimu. Lietuvoje sutrikusio intelekto asmenu psichomotorinès raidos tyrimų atliekama nedaug, o psichomotorinè sutrikusio intelekto asmenu reakcija yra beveik nenagrinèta, nors ji yra vienas iš psichomotorinès būklès rodiklių. Be to, trūksta duomenų, kaip psichomotorinès reakcijos laikas priklauso nuo atlikimo tikslumo ir intelekto sutrikimo laipsnio.

Tyrimo tikslas - ištirti ir îvertinti sutrikusio intelekto asmenų psichomotorinę reakciją. Siek- dami užsibrèžto tikslo stengèmės atsakyti į šiuos klausimus: 1) kaip skiriasi iprastos ir sutrikusios raidos asmenu psichomotorinè reakcija; 2) ar skiriasi sutrikusio intelekto asmenu paprasta ir sudètinga reakcija ị šviesą ir garsą; 3) ar priklauso sutrikusio intelekto asmenu psichomotorinè reakcija nuo sutrikimo laipsnio ir lyties.

\section{TYRIMO METODIKA}

Tiriamieji. Buvo tirtos trys $18-21$ metu amžiaus grupès. Pirmą grupę sudare 20 iprastos raidos Lietuvos kūno kultūros akademijos pirmo ir trečio kurso aktyviai nesportuojančių studentų (amžius 19,6 \pm 1,23 m.; 10 vaikinų, 10 merginų), antrą - 17 Kauno 1-osios specialiosios mokyklos nežymiai protiškai atsilikusių moksleivių, ugdomų lavinamosiose klasèse (amžius 19,5 $\pm 1,18$ m.; 9 vaikinai, 8 merginos), trečią -19 vidutiniškai protiškai atsilikusių asmenų, ugdomų specialiosiose klasėse (amžius 19,4 \pm 1,21 m.; 9 vaikinai, 10 merginu).

Metodas. Tyrimo metu buvo taikomas reakciometrijos metodas naudojant reakciometrą RA-1, skirtą žmogaus reakcijos į raudonos ir žalios šviesos ar i garsini signalą trukmei matuoti, ir žmogaus centrinès nervų sistemos (CNS) psichomotorinès reakcijos greičio ypatumams nustatyti. Prietaisas naudojamas kartu su standartiniu personaliniu kompiuteriu, kuriame įdiegta duomenų apdorojimo programa. Reakcijos laikas i šviesą matuojamas nuo vienos spalvos lemputés užsidegimo momento iki atitinkamo klavišo paspaudimo (jei užsidega žalia — spausti dešini klavišą, jei raudona — kairị). Reakcijos laikas i garsą matuojamas nuo garsinio signalo pradžios momento iki atitinkamo klavišo paspaudimo. Sudètingos reakcijos laiko matavimas gristas atsitiktinumo veiksniu - atsitiktine tvarka užsidega žalia arba raudona lemputè.

Tyrimo organizavimas. Pirmos grupès tiriamieji tirti Lietuvos kūno kultūros akademijos Taikomosios fizinès veiklos katedros auditorijoje, antros ir trečios - Kauno 1-osios specialiosios mokyklos sporto saleje, iš anksto susitarus su mokyklos administracija, tiriamujų tèvais ir globejais.

Tyrimo metu buvo laikomasi šio reakcijos laiko užduočiu atlikimo eiliškumo: kaire ranka i šviesą (KRŠ), dešine ranka i šviesą (DRŠ), kaire ir dešine ranka ị šviesą (KDRŠ), kaire ranka ị garsą (KRG), dešine ranka i garsą (DRG).

Prieš pradėdamas tyrimus kiekvienas tiriamasis buvo supažindinamas su tyrimo metodika, 
atliekami 3 bandomieji reakcijos laiko nustatymo bandymai. Isitikinus, kad tiriamasis tikrai suprato principa, buvo atliekami 20 reakcijos laiko bandymų fiksuojant rezultatą. Tarp atskiru užduočiu daroma $30-40 \mathrm{~s}$ pertrauka. Tiriamasis tyrimo metu patogiai atsisėda prie stalo, tam tikros rankos pirštą laiko ant klavišo ir, užsidegus šviesai ar išgirdus garsą, bando kuo greičiau sureaguoti (paspausti klavišą).

Atliekant tyrimą, trečiai grupei buvo teikiama grižtamoji informacija (tiriamajam reaguojant lèčiau, sakoma „greičiau“ - teikiama informacija apie reakcijos laiko rezultatus), didinama motyvacija skatinamaisiais žodžiais ir pagyrimais atliekant visas užduotis, teikiama papildoma informacija (t. y. yra sudarytas motorinès programos modelis, sakant „kaire“ reaguojama į žalią šviesa, sakant „dešine“ - i raudoną šviesą) atliekant KDRŠ užduoti. Antrai grupei buvo teikiama tik grį̌tamoji informacija atliekant KDRŠ užduoti. Pirmai grupei nebuvo didinama nei motyvacija, nei teikiama grį̌tamoji informacija.

Gautiems tyrimo rezultatams apdoroti taikyti matematinès statistikos metodai. Tyrimo duomenys buvo apdorojami pasitelkiant kompiuterinès programos Microsoft EXCEL skaičiuoklę. Duomenims ivvertinti buvo skaičiuojamas aritmetinis vidurkis $(\bar{x})$, standartinis nuokrypis (Sx). Rezultatų skirtumo patikimumo lygmuo skaičiuotas pagal Stjudento t (Student $t$ ) kriteriju. Vertinant rezultatu patikimumą statistinès analizès metu pasirinktas reikšmingumo lygmuo $\mathrm{p}<0,05$.

\section{REZULTATAI}

Tyrimo duomenų analizè parodè, kad I grupès tiriamuju psichomotorinès reakcijos rezultatai, lyginant su II ir III grupès, geresni atliekant visas reakcijos laiko užduotis (p < 0,05) (žr. lent.).

Nagrinejjant 2 ir 3 grupés tiriamuju reakcijos laiko užduoties rezultatus pastebeta skirtumų. 3 grupès vidutiniškai protiškai atsilikusių tiriamuju kairès rankos reakcija ị šviesa, dešinès rankos reakcija i garsą ir sudètinga reakcija geresnè nei 2 grupès nežymiai protiškai atsilikusių tiriamujų $(\mathrm{p}<0,05)$. Abiejų grupių tiriamujų kairès rankos reakcija i garsa panaši. Tyrimo duomenu analize parodè, kad visu grupių tiriamieji (iprastos ir sutrikusio intelekto raidos) greičiau reaguoja i garso nei į šviesos dirgiklį, nors statistiškai reikšmingas skirtumas nustatytas tik tarp I grupès iprastos raidos ir III grupès vidutiniškai protiškai atsilikusių tiriamuju psichomotorinès reakcijos rezultatu, atliekant reakcijos laiko i garsą ir šviesą dešine ranka užduotis, II grupės nežymiai protiškai atsilikusiu tiriamujų — reakcijos laiko i garsą ir šviesą kaire ranka užduotis $(\mathrm{p}<0,05)$. Paprastos reakcijos laiko į šviesą ir garsą užduočių, sudètingos reakcijos laiko užduoties analizė parodè, kad kur kas blogesnè visų grupių tiriamuju sudètinga psichomotorinè reakcija ( $\mathrm{p}<0,05)$ (žr. lent.).

Tyrimo duomenų analizè lyties aspektu parodè, kad III grupès vidutiniškai protiškai atsilikusios merginos geriau reagavo į šviesą kaire ir dešine ranka nei II grupès nežymiai protiškai atsilikusios merginos $(\mathrm{p}<0,05)(1$ pav.). Panaši tendencija pastebèta ir lyginant sutrikusio intelekto vaikinu reakciją i šviesą kaire ir dešine ranka, nors statistiškai reikšmingų skirtumų nepastebèta. İdomu tai, kad II ir III grupès sutrikusio intelekto merginos reagavo į šviesą greičiau dešine ranka, o I grupès iprastos raidos merginos - kaire. Vaikinų reakcijos į šviesą rezultatai buvo atvirkštiniai - II ir III grupės sutrikusio intelekto vaikinai greičiau reagavo ị šviesą kaire ranka, I grupès iprastos raidos vaikinai - dešine, nors visų grupių tiriamuju dominuojanti ranka buvo dešinè (1 pav.).

III grupès vidutiniškai protiškai atsilikusios merginos greičiau reagavo i garsą dešine ranka nei II grupès nežymiai protiškai atsilikusios merginos $(\mathrm{p}<0,05)(1$ pav.), o kairès rankos reakcija i garsa tarp sutrikusio intelekto merginu beveik nesiskyrè. Tarp sutrikusio intelekto vaikinu reakcijos i garsą kaire ir dešine ranka statistiškai reikšmingo

\begin{tabular}{|c|c|c|c|c|c|}
\hline \multirow{5}{*}{$\begin{array}{r}\text { Statistiniai } \\
\text { rodikliai }\end{array}$} & \multicolumn{5}{|c|}{$\bar{x} \pm \mathbf{s}$} \\
\cline { 2 - 6 } & KR & DRŠ & KDRŠ & KRG & DRG \\
\hline I & $200 \pm 34,5^{*}$ & $194 \pm 30^{*}$ & $323 \pm 21^{*}$ & $191 \pm 20^{*}$ & $297 \pm 32^{*}$ \\
\hline II & $441 \pm 64,5^{* * *}$ & $308 \pm 63$ & $560 \pm 76$ & $317 \pm 38,5^{* * *}$ & $326 \pm 56$ \\
\hline III & $370 \pm 197,5^{* *}$ & $371 \pm 102,5^{* * *}$ & $484 \pm 63^{* *}$ & $318 \pm 57,5$ & $267 \pm 67^{* * *}$ \\
\hline
\end{tabular}

Lentelè. Reakcijos laiko užduočių aritmetiniai vidurkiai

Pastaba. Reakcijos laiko užduočių atlikimo eiliškumas: KRŠ — kaire ranka į šviesą; DRŠ — dešine ranka į šviesą; KDRŠ — kaire ir dešine ranka į šviesą; KRG — kaire ranka ị garsą; DRG — dešine ranka i garsą. * — skirtumas tarp I ir II—II gr. p < 0,05; ** — skirtumas tarp I ir II gr. $\mathrm{p}<0,05 ; * * *$ _ skirtumas tarp reakcijos laiko į šviesą ir garsą. 
1 pav. Vaikinų ir merginų reakcijos laiko užduočių aritmetinių vidurkių palyginimas
Pastaba. KRŠ — kaire ranka ị šviesą; DRS̆ dešine ranka ị šviesą; KDRŠ — kaire ir dešine ranka į šviesą; KRG - kaire ranka i garsą; DRG - dešine ranka i garsą. * $-\mathrm{p}<0,05$.

2 pav. Sudėtingos reakcijos laiko užduoties klaidu vidurkis
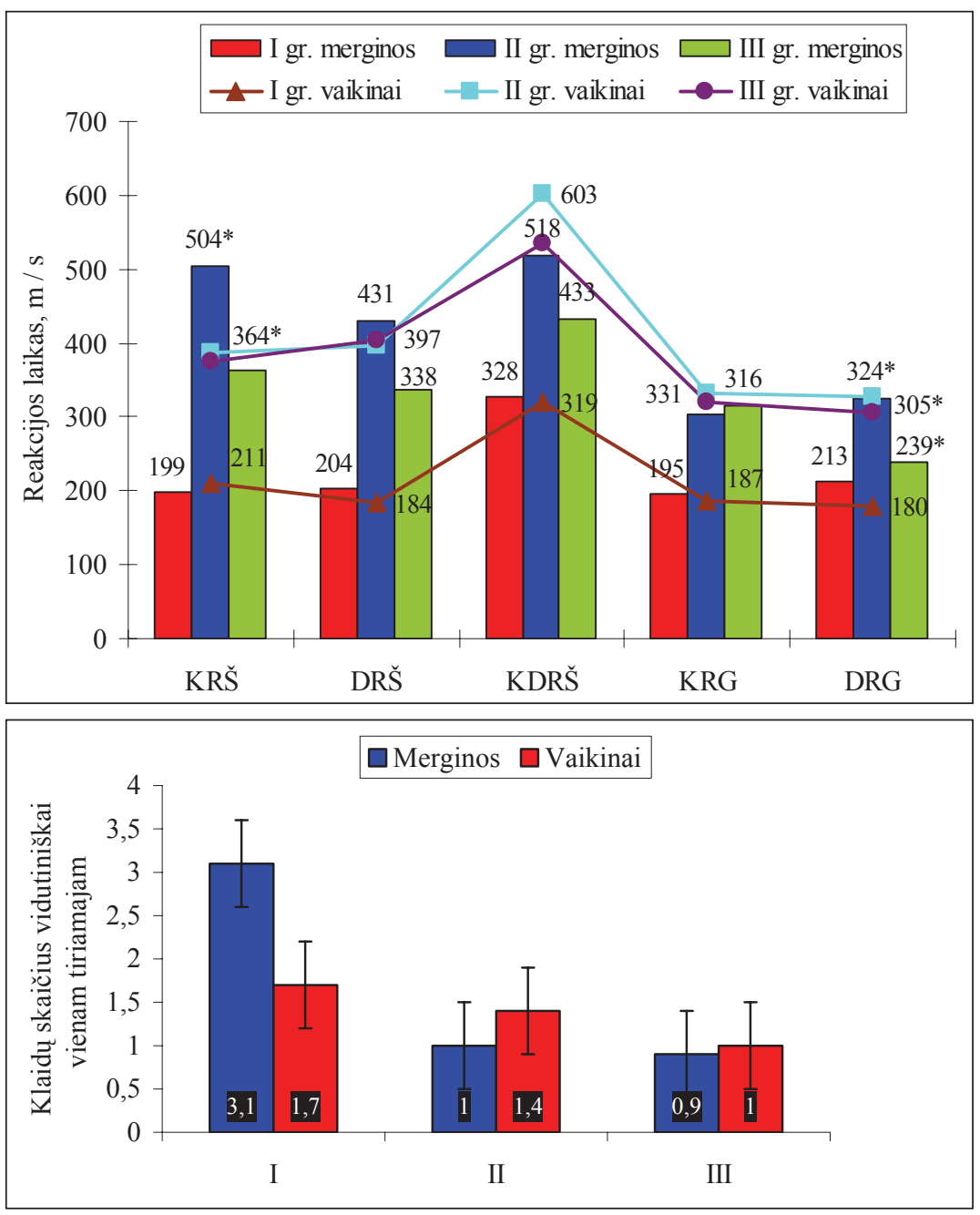

Atlikdamos sudètingos reakcijos laiko užduoti (KDRŠ) greičiau reagavo II ir III grupès protiškai atsilikusios merginos nei II ir III grupès protiškai atsilikę vaikinai $(p<0,05)$. Iprastos raidos (I grupès) vaikinai buvo greitesni nei merginos, tačiau statistiškai reikšmingo skirtumo nenustatyta (1 pav.).

Tiriamiesiems atliekant reakcijos laiko i garsą užduotis pastebimas panašus rezultatu pasiskirstymas, kaip ir atliekant sudetingos reakcijos laiko užduotị: protiškai atsilikusios merginos reagavo greičiau negu protiškai atsilikę vaikinai (1 pav.). Statistiškai reikšmingas skirtumas pastebètas tik atliekant reakcijos i garsą dešine ranka užduoti III grupès vidutiniškai protiškai atsilikusios merginos reagavo greičiau nei III grupès vidutiniškai protiškai atsilikę vaikinai $(\mathrm{p}<0,05)$.

Sudètingos psichomotorinès reakcijos analizè klaidų požiūriu parodé, kad daugiausia klaidų darè iprastos raidos tiriamieji (1 grupès), mažiausiai vidutiniškai protiškai atsilikę tiriamieji (3 grupès) (2 pav.).

Lyginant protinio atsilikimo grupių rezultatus tarpusavyje pastebėta, kad nežymaus protinio 
atsilikimo merginos ir vidutinio protinio atsilikimo vaikinai padarè vidutiniškai po vieną klaidą. Mažiausiai klaidų darè vidutinio protinio atsilikimo merginos, daugiausia - nežymaus protinio atsilikimo vaikinai, tačiau statistiškai reikšmingo skirtumo nebuvo nustatyta $(\mathrm{p}>0,05)(2 \mathrm{pav}$.).

\section{REZULTATUQ APTARIMAS}

Atliekant judesius svarbu gebèti ne tik atlikti pati judesi, bet ir esant tam tikroms salygoms ji kuo greičiau pradèti, t. y. turèti gerą reakciją. Reagavimo greitis priklauso nuo daugelio komponentų: nervinio signalo siuntimo ị centrinę nervų sistemą (CNS), sprendimo prièmimo, judesiu programos sudarymo, siuntimo i raumenis spartos. Reakcija būna paprasta ir sudetinga. Paprasta reakcija tokia, kai veikia vienas, iš anksto žinomas dirgiklis (signalas) ir būdas, kaip i ji atsakyti. Sudetingos reakcijos ypatumas - galimi keli dirgikliai, i kuriuos atsakoma keliais būdais (Zuozienè ir kt., 2007). Mūsu tyrimo metu tiriamiesiems atliekant pateiktas užduotis buvo tirta paprasta ir sudètinga reakcija.

Skirtingų grupių tiriamujų rezultatų analizė parodè, kad iprastinès raidos tiriamieji, lyginant su protiškai atsilikusių grupèmis, pasiekè daug geresnių rezultatų atlikdami visas reakcijos užduotis, $(\mathrm{p}<0,05)$. Vadinasi, galima būtų daryti prielaida, kad reakcijos laiko rezultatus lemia intelekto sutrikimo lygis. Tokias prielaidas nurode ir kiti tyrèjai (Kioumourtzoglou et al., 1994; Lahtinen et al., 2007; Lina et al., 2009). Mūsų tyrimo metu tiriamiesiems buvo duota užduotis kuo greičiau sureaguoti i šviesos ar garso dirgikli (tai rodo asmens gebejjimą greitai apdoroti informacija). Todèl šiuos rezultatus galima paaiškinti taip: sutrikusio intelekto asmenims sunkiau suprasti, iciminti ir apdoroti informaciją, susijusią su greičiu ir judesio tikslumu. Remiantis Fitts dėsniais, asmenys kontroliuoja savo reakcijos būdą, todèl jie gali labai greitai reaguoti i dirgikli, bet ne taip tiksliai, arba labai tiksliai atlikti judesi, bet ne taip greitai (Zuozienè ir kt., 2007). Gautuosius rezultatus patvirtina ir kitų atlikti tyrimai (Weeks et al., 2000; Song, An, 2004; Carmeli et al., 2007; Carmeli et al., 2008; Wuang et al., 2008). Skirtingu grupiu tiriamuju rezultatu analizè parodè, kad iprastinès raidos ir protiškai atsilikę tiriamieji reagavo greičiau i garso nei į šviesos dirgiklį. Panašius tyrimo duomenys pateikè ir kiti tyrejai (Robertson et al., 2002; Di Blasi et al., 2007; Wuang et al., 2009). Tokius rezultatus galètų paaiškinti skirtingi fizinio ugdymo ypatumai. Ugdant vyrauja daugiau žodinè motorine integracija nei regimoji motorinè, ir tai gali būti regimosios motorinès integracijos problema (Weeks et al., 2000).

Atlikus reakcijos laiko duomenų analizę nustatyta, kad nežymaus protinio atsilikimo vaikinų reakcijos laikas į šviesą buvo geresnis nei to paties protinio atsilikimo merginu. Tai sutampa su kitų tyrèjų duomenimis (Un, Erbahęeci, 2001; Robertson et al., 2002; Heath et al., 2007; Hale et al., 2009), kurie nurode sutrikusio intelekto vaiku ir paaugliu reakcijos laiko skirtumus lyties požiūriu. Lyginant vidutinio protinio atsilikimo vaikinus ir merginas pastebèta, kad greičiau reaguoja merginos nei vaikinai. Mūsų tyrimo rezultatai galètu prieštarauti D. J. Weeks, R. Chua ir D. Elliott (2000) išvadai, kad protiškai atsilikusių berniukų fizinis pajègumas ir judesiu greitis yra geresni negu protiškai atsilikusių merginų, ir šis skirtumas tarp lyčių dideja priklausomai nuo atsilikimo lygio.

Tyrimo metu $18-21$ metu vidutiniškai protiškai atsilikusiems vaikinams ir merginoms atliekant visas reakcijos laiko užduotis buvo naudojami atsako i dirgiklį motyvaciją skatinantys žodžiai ir teikiama grižtamoji informacija. Taigi manytume, kad šie veiksmai turejo didelę itaką rezultatams vidutinio protinio atsilikimo tiriamuju reakcijos laikas buvo geresnis negu nežymiai protiškai atsilikusių tiriamujų. Panašius rezultatus nurode ir kiti tyrejai teigdami, kad judesi skatinanti motyvacija ir grižtamoji informacija sutrumpina reakcijos laiką (Weeks et al., 2000).

Sudetingos reakcijos laiko rezultatai yra daug blogesni nei paprastos reakcijos. Kuo sudètingesnis judesys, tuo jis atliekamas lěčiau, nes ilgiau galvos smegenyse kuriamas judesio planas, judesio programa ir daugiau laiko reikia jai realizuoti (Zuozienė ir kt., 2007). Tai iš dalies patvirtina ir mūsų tyrimo rezultatai, nes sudètingos reakcijos užduočiu atlikimo greitis buvo daug lètesnis nei paprastos. Mokslininkai (Weeks et al., 2000; Mohan et al., 2001; Song, An, 2004; Carmeli et al., 2007; Carmeli et al., 2008; Wuang et al., 2008) šiu reakcijų skirtumą aiškina Hick dèsniu kuo daugiau informacijos perduodama impulsu, tuo ilgesnis reakcijos laikas. Informacijos kiekis priklauso nuo to, kiek tiketinas ir laukiamas yra impulsas. Taip pat didelę itaką tam daro dirgiklio nežinomumas ir netikètumas (tiriamieji iš anksto nežinojo, i kurią šviesą (raudoną ar žalią) ir kada reikès reaguoti).

Vertinant psichomotorinès reakcijos užduoties metu atliekamas klaidas reikètu pažymèti, kad 
protiškai atsilikusiems tiriamiesiems buvo nurodomos klaidos (ir jie patys jas pripažino), ir tai lèmé geresnį reakcijos laiką bei mažesnị klaidų skaičių. Taigi protiškai atsilikę tiriamieji gebejjo panaudoti turimą informaciją ir pasiruošti reikiamam judesiui prieš ji atlikdami. Nors protiškai atsilikusių tiriamujų reakcijos laikas buvo ilgesnis nei iprastos raidos asmenu, tačiau jie įvairiomis sąlygomis tą pati judesi atliko stabiliau (Weeks et al., 2000). Kita vertus, protiškai atsilikę tiriamieji reakcijos laiko užduotis atliko kur kas dinamiškiau. Vadinasi, šie tiriamieji gebejo sudaryti motorinę programą ir ją tobulinti kaip ir iprastos raidos asmenys (Weeks et al., 2000; Song, An, 2004).

Palyginus ir apibendrinus visų trijų tirtu grupių rezultatus galima teigti, kad protiškai atsilikusiems asmenims tiesiog reikia daugiau laiko tam pačiam regimosios ar girdimosios informacijos kiekiui apdoroti (Weeks et al., 2000). Sudètingos reakcijos laiko rezultatų klaidų analizė dar kartą patvirtina teigini, kad motyvacija ir grižtamosios informacijos teikimas teigiamai veikè reakcijos laiko rezultatus, mažino klaidų skaičių (Weeks et al., 2000; Planinsec, Pisot, 2006 ).

\section{IŠVADOS}

Iprastinès raidos tiriamieji pasiekè daug geresnių rezultatų atlikdami visas reakcijos laiko nustatymo užduotis, lyginant su protiškai atsilikusių tiriamuju grupèmis $(p<0,05)$. Iprastos raidos tiriamieji darè daugiau klaidų nei sutrikusio intelekto asmenys, mažiausiai klaidų darė vidutiniškai protiškai atsilikę tiriamieji.

Visų grupių tiriamieji greičiau reagavo į garso nei $\mathfrak{i}$ šviesos dirgikli, ir jų paprastos reakcijos laiko rezultatai buvo geresni nei sudètingos.

Nežymiai protiškai atsilikusių vaikinų reakcijos laikas buvo geresnis atliekant paprastos reakcijos laiko ị šviesą užduotis, o to paties protinio atsilikimo merginos reagavo greičiau i paprastos reakcijos i garsą užduotis. Vidutiniškai protiškai atsilikusių merginų reakcija į šviesą ir garsą yra geresnè nei to paties protinio atsilikimo vaikinų.

\section{LITERATŪRA}

Carmeli, E., Bar-Yossef, T., Ariav, C. et al. (2008). Sensory motor impairments and strategies in adults with intellectual disabilities. Motor Control, 12 (4), 348-361.

Carmeli, E., Bar-Yossef, T., Ariav, C., Levy, R., Libermann, D. G. (2007). Perceptual - motor coordination in persons with mild intellectual disability. Journal of Disability Rehabilitation, 10 (5), 1-7.

Di Blasi, F. D., Elia, F., Buono, S., Ramakers, G. J., Di Nuovo, S. F. (2007). Relationships between visual-motor and cognitive abilities in intellectual disabilities. Journal of Perceptual Motor Skills, 104 (3), 763-72.

Griniene, E. ir Puidaite, A. (2003). Nežymiai protiškai atsilikusiu paauglių fizinio pajègumo raidos ypatumai. Specialusis ugdymas, 1 (8), 40-46.

Gut, M., Urbanik, A., Forsbero, L. et al. (2007). Brain correlates of right - handedness. Acta Neurobiologiae Experimentalis, 67 (1), 43-51.

Hale, L., Miller, R., Barach, A., Skinner, M., Gray, A. (2009). Motor control test responses to balance perturbations in adults with an intellectual disability. Journal of Intellectual \& Developmental Disability, 34 (1), 81-87.

Heath, M., Grierson, L., Binsted, G., Elliott, D. (2007). Interhemispheric transmission time in persons with Down syndrome. Journal of Intellectual Disability Research, 51 (12), 972-981.

Jang, Y., Chang, T. C., Lin, K. C. (2009). Reliability and validity of a physical capacity evaluation used to assess individuals with intellectual disabilities and mental illness. International Journal of Rehabilitation Research, 32 (1), $77-84$.

Kioumourtzoglou, E., Batsiou, S., Theodorakis, Y., Mauromatis, G. (1994). Selected motor skills of mentally retarded and non-retarded individuals. Journal of Perceptual Motor Skills, 78 (3), 1011-1015.

Lahtinen, U., Rintala, P., Malin, A. (2007). Physical per- formance of individuals with intellectual disability: A 30 year follow up. Adapted Physical Activity Quarterly, 24 (2), 125-143.

Lin Y. L., Chen, M. C., Chang, Y. T., Yeh,C. C., Meng, L. F. (2009). The performance of mouse pointing and selecting for pupils with and without intellectual disabilities. Research in Developmental Disabilities, 30 (6), 11881195.

Mohan, A., Singh, A. P., Mandal, M. K. (2001). Transfer and interference of motor skills in people with intellectual disability. Journal of Intellectual Disability Research, 45 (4), 361-369.

Planinsec, J., Pisot, R. (2006). Motor coordination and intelligence level in adolescents. Adolescence, 41 (164), $667-676$.

Pratt, H. D., Greydanus, D. E. (2007). Intellectual disability (mental retardation) in children and adolescents. Primary Care, 34 (2), 375-386

Robertson, S. D., Van Gemmert, A. W., Maraj, B. K. (2002). Auditory information is beneficial for adults with Down syndrome in a continuous bimanual task. Acta Psychologica, 110 (2-3), 213-29

Song, K. Y., An, J. D. (2004). Premotor and motor reaction time of educable mentally retarded youths in a Taekwondo program. Journal of Perceptual Motor Skills, 99 (2), $711-723$.

Un, N., Erbahçeci, F. (2001). The evaluation of reaction time on mentally retarded children. Pediatric Rehabilitation, 4 (1), 17-20.

Weeks, D. J., Chua, R., Elliott, D. (2000). Perceptual Motor Behavior in Down Syndrome. Human Kinetics.

Wuang, Y. P., Lin, Y. H., Su, C. Y. (2009). Rasch analysis of the Bruininks-Oseretsky Test of Motor ProficiencySecond Edition in intellectual disabilities. Research in Developmental Disabilities, 30 (6), 1132-1144. 
Wuang, Y. P., Su, C. Y. (2009). Rasch analysis of the Developmental Test of Visual-Motor Integration in children with intellectual disabilities. Research in Developmental Disabilities, 30 (5), 1044-1053.

Wuang, Y. P., Wang, C. C., Huang, M. H., Su, C. Y. (2008). Profiles and cognitive predictors of motor functions among early school-age children with mild intellectual disabilities. Journal of Intellectual Disability Research, 52 (12), $1048-1060$.
Wuang, Y. P., Wang, C. C., Huang, M. H., Su, C. Y. (2009). Prospective study of the effect of sensory integration, neurodevelopmental treatment, and perceptual-motor therapy on the sensorimotor performance in children with mild mental retardation. The American Journal of Occupational Therapy, 63 (4), 441-452.

Zuozienè, I. J., Skurvydas, A., Mickevičienè, D. (2007). Judesių reakcijos laiko ir greičio analizè. Sporto mokslas, 1 (47), $40-47$.

\title{
PECULIARITIES OF PSYCHOMOTOR REACTION OF PERSONS WITH INTELLECTUAL DISABILITIES
}

\author{
Diana Rèklaitienė, Dovilè Selickaitė, Jūratė Požerienė \\ Lithuanian Academy of Physical Education, Kaunas, Lithuania
}

\begin{abstract}
Research methods of human reactions to various signals enable us to discover new features and to formulate new attitude to general activities of proprioreception, apparatus of balance, visual and nerve — muscle systems (Weeks et al., 2000; Gut et al., 2007; Zuozienè et al., 2007). Psychomotor reaction is important for persons with intellectual disabilities during daily life activities, work and participation in sport or recreation activities. Sometimes it is important to make fast decisions, appropriate actions in usual or unexpected situations (Weeks et al., 2000; Pratt, Greydanus, 2007). One of peculiarities of development of persons with intellectual disabilities is delayed psychomotor development; and for investigations in this theme will help to observe the changes of CNS functional conditions. Reaction time is important not only for motor development of the intellectually disabled, but also for their faster and better adjustment according to changing life conditions.

The aim of the research was to evaluate the peculiarities of psychomotor reaction of persons with intellectual disabilities. The research questions were as follows: 1) what are the differences of psychomotor reactions between persons with normal development and with intellectual disabilities; 2) are there any differences between simple and complex reaction to light and sound of persons with intellectual disabilities; 3 ) are there any differences of psychomotor reaction of the intellectually disabled according to the level of their disability and gender. The research participants were 18-21 years-old persons with normal development $(n=20)$, persons with mild mental retardation $(n=17)$ and persons with moderate mental retardation $(n=19)$. Analyzer RA-1 was used to measure psychomotor reactions of the participants. The research participants performed three tasks - reaction time to green and red light, reaction time to sound and reaction speed. Research results indicated that the group of persons with normal development demonstrated significantly better results of reaction time $(\mathrm{p}<0.05)$ compared to both groups of persons with intellectual disabilities. Reaction time to sound was shorter compared to the reaction to light. The reaction time of simple task was shorter compared to complex task in all groups of the research participants. Men with mild mental retardation demonstrated shorter reaction time performing simple tasks to the light, while women with the same level of disability reacted faster performing a simple task to sound. Reaction time performing a simple task to light and sound was shorter for women with moderate mental retardation compared to men with the same level of disability. Able-boded research participants made more mistakes during the reaction time tasks compared to the participants with mental retardation.
\end{abstract}

Keywords: intellectual disabilities, psychomotor reaction, reaction time.

Gauta 2009 m. lapkričio 4 d.

Received on November 4, 2009

Priimta $2010 \mathrm{~m}$. balandžio $1 \mathrm{~d}$.

Accepted on April 1, 2010
Diana Rèklaitienè

Lietuvos kūno kultūros akademija

(Lithuanian Academy of Physical Education)

Sporto g. 6, LT-44221 Kaunas

Lietuva (Lithuania)

Tel +370 37302660

E-mail d.reklaitiene@1kka.1t 